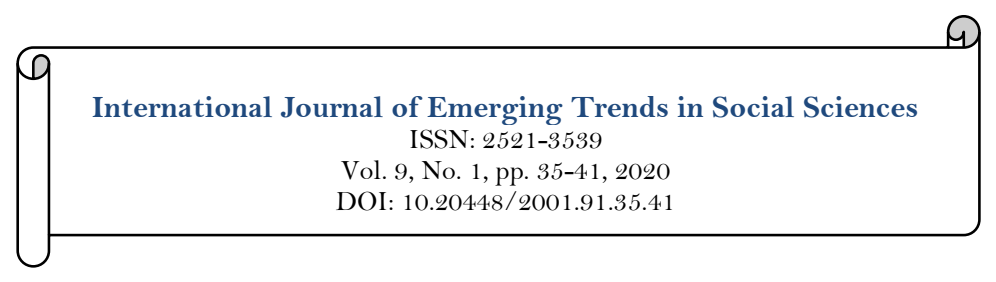

$\checkmark$ updates

\title{
Antecedent of Foreign Direct Investment in Developing Countries: Evidence from Pakistan
}

\author{
Rehana Fayyaz ${ }^{1}$ \\ Hafiz Muhammad Naveed ${ }^{2 *}$ \\ Yao Hongxing ${ }^{3}$
}

'School of Management, National College of Business Administration \&' Economics, Bahawalpur, Pakistan.

${ }_{2, s}$ School of Finance and Economics, Jiangsu University, Jiangsu Province, China.

${ }^{2}$ Email: hafiznaveed778@gmail.com

\section{Abstract}

The proposed present research study estimates the role of foreign direct investment in developing economies. This research study also determines the factors affecting foreign direct investment in developing countries. For this key purpose, we have collected time-series data from the official website of world development indicators, Pak economic survey $\mathcal{E}^{2}$ the state bank of Pakistan since 1981 to 2019. The autoregressive distributive lag model has been applied to evaluate the association among the variables. Afterward, the bond test has also been utilized to estimate the long-run relationships between dependent and predicted variables. The results indicate that there is a significant relationship between gross domestic product growth and the trade deficit with foreign direct investment. Moreover, there has neither a positive nor negative association of the real rate of interest and tax rate with foreign direct investment. The current research study concludes that foreign direct investment inflows are significantly promoting developing economies.

Keywords:

Foreign direct investment

Real rate of interest

Trade deficit

Gross domestic product

Growth rate

Tax rate.

Licensed:

This work is licensed under

Creative Commons Attribution 4.0

License.

Publisher:

Scientific Publishing Institute

Received: 9 September 2020

Revised: 1 October 2020

Accepted: 12 October 2020

Published: 21 October 2020

Funding: This study received no specific financial support.

Competing Interests: The authors declare that they have no competing interests.

Acknowledgement: Authors are indebted to all anonymous reviewers for significantly improved their quality of work

via valuable comments and suggestions. Authors are appreciating and thankful for their commentarial contributions.

\section{Introduction}

In the previous, there is an outsized volume of studies that specialize in the reason that affects the flow of outside country capital into industrialized or rising marketplace. Similarly, some other scholars have discussed on social and political issues like the dullness catalog of desirable capital countries. The determinants of FDI don't seem to be identical in numerous global regions. Through comparison, foreign investment flows into emergent countries in the geographical area, establish things like come from the backside of the capital and higher infrastructure to possess an encouraging impact on foreign investment in developing countries while that they had no significant effect in different countries. Likewise, a massive openness of trade has a more substantial impact on foreign direct investment into developing economies.

An additional cluster of different studies wanted to spot variables concerning the size of the market place and factors, like country political condition, Gross domestic products (G.D.P.), exports, and country other risk 
enchanting into thought the direct effect on receiver countries or the indirect impact on countries that, in essence, vie for foreign direct investment quantity. Additionally, some studies on similar phenomenon conjointly enclosed factors concerning each finance of the target countries and others to spot the determents of a rich countries investment in the rising marketplace. Victimization information from 1984 to 2015 estimated the relation exports and G.D.P. for South Korea, Malaysia, Taiwan, China, Singapore, Philippines received the foreign investment of different regions (de Angelo, Eunni, \& Fouto, 2010). On the other hand, governments also are engaged in an exceeding strategy opposition by sterilization key factors of their economic strategy, equivalent to within-country labour market situation, company tax, tariff blockade, subsides, privatization more restrictive governmental enforcement, to boost foreign investment activities in their countries (Agiomirgianakis, Asteriou, \& Papathoma, 2003). Foreign Direct Investment plays a crucial role in developing the economy, and it's a significant supply of external finance in the Asian nation to stable business, monetary and trade policies. The most objective of our study is to quantify the impact of various factors like G.D.P., Infrastructure, Political Stability, Terrorism, proletariat on FDI. During the investigation, we tend to estimate that Foreign Direct Investment encompasses a hope in boosting the G.D.P. growth ends up in the foundation of the business sector. By adopting policies to acquire more investment has many effects on the economy's growth (Ibrahim, 2019; Kinuthia \& Murshed, 2015). Internal factors can be easily controllable by entrepreneurial but external factors are beyond the control of the owner (Galan \& GonzalezBenito, 2001). Likewise, the corporate tax incentive is a policy instrument mainly used in many countries to attract foreign investment as FDI increases the productivity and economic growth in host countries (Deng, Falvey, \& Blake, 2012).

On the other hand, the current account deficit (CAD) means that the amount by which the country's imports exceed as compare exports. In the same way, when there has CAD, then it is an attractive situation for foreign investors to come in the country and produce the goods there as compare to export there and increase the profitability (Shankar \& Yadav, 2014). Additionally, the tax rate has effects on business decisions in domestic as well as foreign markets. A low tax rate acquires a high amount of profit on the investment means a low tax rate causes a high return on investment; it increased the gain of the investors. A high tax rate is the main barrier for foreign direct investment or foreign investors (Chingarande et al., 2012). They addressed that the corporate tax is harmful to foreign direct investment inflow. But in few studies identified that the taxes have no significant contribution to attract FDI (Bachmann \& Baumann, 2013). But majority scholars mention that there is an inverse relationship between tax rate and local investment (Ali \& Malik, 2017).

Pakistan is a developing country, but there have several natural and human resources. There have insufficient resources for optimal utilization of these natural resources (Jones, Fallon, \& Golov, 2000; Malik \& Amjad, 2013).The GDP-growth rate, Wage Rate, Per Capita Income, Tax Brackets, Low-Interest Rate, Low Inflation, Effective Labour, Efficient Market, Political and Economic Stability all above are attracting components to foreign investors (Kersan-Škabić, 2015). For this purpose, the Pakistani administration has essentially needed to set special legislation for the tax section for the attraction of FDI or foreign investors and utilization of resources (Masso, Roolaht, \& Varblane, 2013). Low tax rates should be a specialty in the country and give tax supports for foreign investors. Low tax is advantageous for attracting FDI, and it is conducive to developing economies (Bachmann \& Baumann, 2013; Hartman, 1984; Ibrahim, 2019). For stability of FDI in a developing country, there is must be needed for low taxation policies that are attractive to foreign investors (Sandhu \& Gupta, 2016).

The main objective of the present study is to expose the hide relation among FDI and tax rate, trade deficit, G.D.P. growth rate and the real rate of interest in developing countries. Moreover, how FDI inflows are doing key role plays in promoting the developing economies, typically the economy of Pakistan. Besides, FDI is directly promoting underlying sectors which indirectly cause to raise the economy. The remaining study will contain on following section: section two will consist of a literature review and hypothesis; $3^{\text {rd }}$ section will consist of empirical methodology; $4^{\text {th }}$ section will consist of results and discussion; $5^{\text {th }}$ section will consist of conclusion and recommendation.

\section{Literature Review}

Since several previous decades, developing countries are noticed by international organizations like the World Development Bank (W.D.I.) and the International Monetary Fund (I.M.F.). They are trying to remove hurdles from the way of foreign direct investment and exploring the policies and procedures to attract foreign direct investment because foreign direct investment provides economic benefits to the host economies. Foreign direct investment is one of the central and essential sources of funds for the gross national investment and it also helps to deprive the trade deficit for the last many years. Foreign direct investment is also increasing its share in the gross domestic products of that economy. Foreign direct investment is playing a vital role in speeding up the growth in developing countries. But developing countries are mainly facing current account deficit problems and massive capital outflow to developed countries (Vegh, 2015).

H1: There is a positive and significant relation between G.D.P. growth rate and FDI

Pakistan is a developing country and facing the problem of the current account deficit since the last five decades. Essentially, Pakistan needs capital flow by developed countries in each sector. So that foreign 
investment focused on consumption and non-tradable goods like oil, banking, gas, food and telecom as compare to tradable items that lead to enhance exports and increase savings. In the past, scholars were showed that foreign investment increases in home output but did not mention the exports of Pakistan in such aspects. FDI is also helpful in improving production capability, market size, employment rate, research and development, improved living conditions or economic growth and technological improvement. In the foreign direct investment, the foreign companies of developed countries transfer their technology in the developing countries that cause pressure on the domestic firm to use the same level of technology to compete for the competition in the market and give the competitors a less competitive advantage and work more effectively and efficiently (Lu, Tao, \& Zhu, 2017). On the other hand, financial legislation of the host country, tax restructures system and privatization policies are not significant with FDI attraction. Overall the researcher talks about the economic openness, effect of privatization, tax structure, the real rate of interest (R.R.I.) and current account deficit (Trevino \& Grosse, 2002).

H2: There is a negative and significant relation between Tax rate and FDI.

H3: There is a positive and significant relation between RRI and FDI.

Over time, they become more capable of handling all types of situations and also improve their skills in management, new technology and communication. Foreign direct investment not only directly increases employment opportunities but also indirectly increase jobs like providing raw material for production. Foreign direct investment is gaining importance for the economy because it causes positive effects on the revenue of the host country. Foreign direct investment is crucial because it increased the capital account surplus that improves the overall trade deficit (Trevino \& Grosse, 2002).

\section{H4: There is a positive and significant relationship between the Trade deficit and FDI}

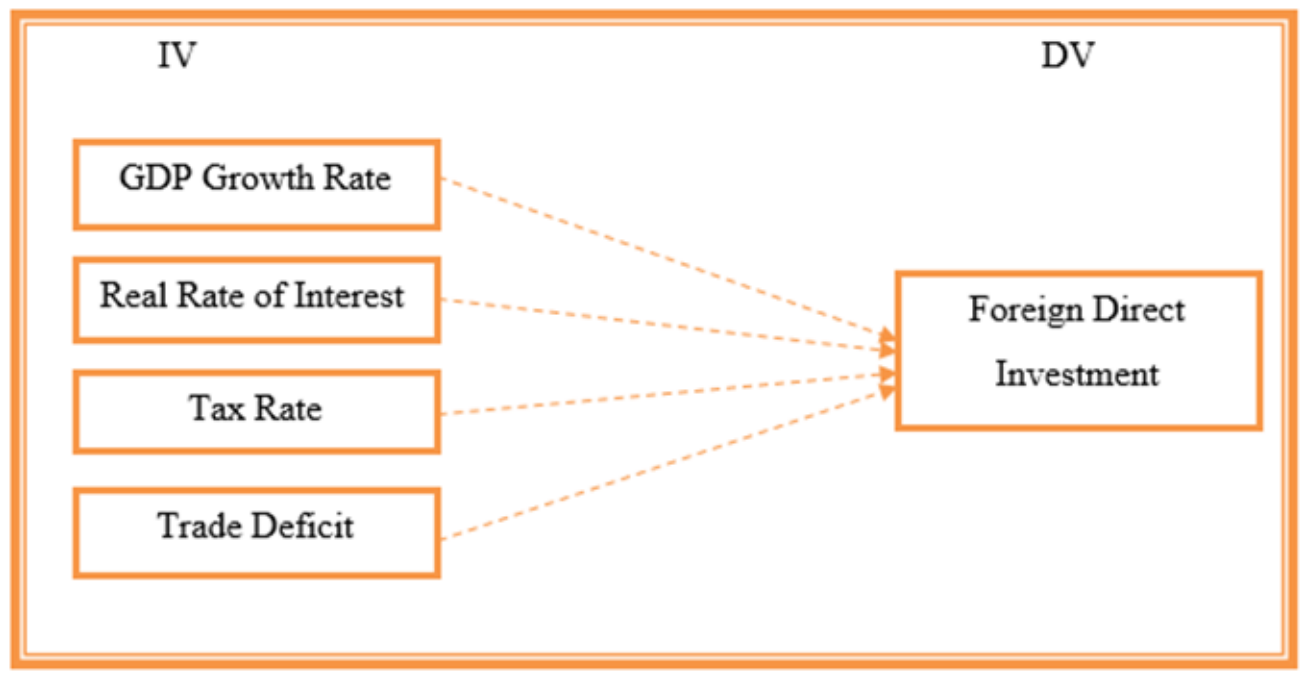

Figure-1. Conceptual model.

Source: Faroh and Shen (2015); Siddiqui and Aumeboonsuke (2014).

\section{Research Methodology}

3.1. Research Population E Data Sampling

The population of the study is addressing as the total number of all units from where data collected. Boddy (2016) precise that the population is the sum of all individuals and organizations. The population of the present research study has contained on Tax Rate, Trade Deficit; Interest Rate; Real Rate of Interest and GDP Growth Rate of Pakistan. A small portion of the population which represents the whole population is considered the sample of the population (Rajasekar, Philomonathan, \& Chinnathambi, 2006). The current research study has taken 39 years of data from 1981 to 2019 to examine the research objective. The data has been collected from the official website of World Development Indicators (WDI), Pak Economic Survey \& State Bank of Pakistan (SBP).

\subsection{Data Analysis Techniques}

Data analysis techniques are quite a significant part of the research methodology. Research Techniques are always used with due respect to the nature of the data. The entire study is adopted the following research techniques under the candlelight of literature to predict the time series annually based data:

\subsubsection{Unit Root Test}

Essentially, the most crucial step before empirical evaluation of the model is to test the stationary of data otherwise the outcome will consider spurious. It is essential to check the stationary of variable individually. 
There are several methods to examine the stationary of data and Augmented Dickey-Fuller (ADF) is a higher credible approach from them. Besides, we can summarize the stationary of the data in the following ways:

$$
\begin{gathered}
\Delta Y_{t}=\beta 1+Z Y_{t-1}+a_{i}+e_{t} \\
\Delta Y_{t}=\beta 1+\beta 2_{t}+Z Y_{t-1}+a_{i}+e_{t}
\end{gathered}
$$

$$
\Delta Y_{t}=Z Y_{t-1}+a_{i}+e_{t}
$$

The above equations indicate that the nature of the data. In Equation 1 has been contained only on-trend; In Equation 2 has summarized on-trend and intercept and the Equation 3 has consisted of no trend and intercept.

\subsubsection{Optimal Lag Length Criteria for ARDL Model}

We have determined the lag length and perceives the size, we used it in the ADF test to prescribe the variables stationary that have utilized underlying model. This is doing with Vector Auto Regressive Specification Order Criterion (VARSOC) table. In econometrics assumptions, an optimum lag selection is a model for time arrangement information in which a relapse condition is utilized to forecast current estimations of a dependent variable given both the present estimates of an explanatory variable and the slacked assessments of this logical variable. The beginning stage for an appropriated lag model is an expected structure of the frame:

$$
Y_{t}=\alpha+w 0 x t+w 1 x 1+w 2 x_{t-2}+\cdots+\text { Error tesm }
$$

Whereas:

In Equation 4 the $\mathrm{y}_{\mathrm{t}}$ is the incentive at area $\mathrm{t}$ of the imperative variable $\mathrm{y}$; on the other side, $\mathrm{w}_{\mathrm{i}}$ is known as the lag weight (likewise to be evaluated) put on the respect i periods already of the illustrative variable $\mathrm{x}$. In principle condition, the dependent variable is thought to be influenced by estimations of the independent variables discretionarily far previously, so the quantity of lag weights is unbounded and the model is called an enormous dispersed lag model.

\subsubsection{Autoregressive Distributed Lag Model}

Autoregressive Distributed Lag (ARDL) Co-integration technique is most obligatory for addressing variables that are integrated of various order and worthy long-run relationship among underlying variables. The time-varying associations of underlying variables, this is detected by the F-statistic (Wald test). During this approach, the long haul relationship of the series is alleged to be established once the F-statistic exceeds the crucial price band (Nkoro \& Uko, 2016). The bond test is covering the number of conceivable characterization of the factors. If the estimation of F-statistic lies over the upper Bond, that displays the nearness of co-joining for the long run period (Sahoo \& Das, 2012).

$$
\Delta \mathrm{FDI}_{\mathrm{it}}=\alpha \mathrm{O}+\beta 1-\mathrm{t} \Delta \mathrm{GDP}+\beta 2-\mathrm{t} \Delta \mathrm{TD}+\beta 4-\mathrm{t} \Delta \mathrm{Tax}+\beta 4-\mathrm{t} \Delta \mathrm{RRI}+\text { Error term }
$$

Whereas:

In Equation 5 explained the ARDL model where FDI are representing explained variable on the time $t, \alpha_{0}$ is intercept, Betas are denoting coefficient of explanatory variables, GDP, TD, Tax \& RRI are explanatory variables, and error term address the stochastic of model error.

\subsubsection{Long \& Short Dynamics}

To estimates the long and short dynamics afterward, make sure the long run Co-integration among the variables. The following credible models measure the long term coefficient:

$$
\mathrm{FDI}_{\mathrm{t}}=\alpha_{0}+\sum_{\mathrm{i}=1}^{\mathrm{n}} \beta_{\mathrm{i}}(\mathrm{TR})_{\mathrm{t}-1}+\sum_{\mathrm{i}=0}^{\mathrm{n}} \delta_{\mathrm{i}}(\mathrm{RRI})_{\mathrm{t}-\mathrm{i}}+\sum_{\mathrm{i}=0}^{\mathrm{n}} \gamma_{\mathrm{i}}(\mathrm{TD})_{\mathrm{t}-\mathrm{i}}+\sum_{\mathrm{i}=0}^{\mathrm{n}} \theta_{\mathrm{i}}(\mathrm{GDPG})_{\mathrm{t}-\mathrm{i}}+\mathrm{e}_{\mathrm{i}}
$$

The Equation 6 are explained the short-long dynamics of co-integration among underlying empirical variables. With respect entire equation, FDI is explained variable on time t, TR, RRI, TD \& GDPG are explanatory variables on time $\mathrm{t}-\mathrm{i}$, sigma is sum of the explanatory variables on the number of observation $\mathrm{n}$, and $e_{i}$ is the stochastic error term for the long term coefficient measurement.

The co-integration term is known as the error correction term while the divergence from the long term path is corrected steadily through several fractional adjustments. The error correction mechanism (ECM) also measures the pace of connection, which shows the rate of adjustment back to long-run stability after a short run disorder. The standard ECM involves estimating the following equation. 


$$
\begin{gathered}
\Delta F D I_{t}=\theta_{1} \pi_{0} E C M_{t-1}+\sum_{i=1}^{n} \alpha_{i} \Delta(T R)_{t-1}+\sum_{i=1}^{n} \beta_{i} \Delta(R R I)_{t-1}+\sum_{i=1}^{n} \vartheta_{i} \Delta(T D)_{t-1} \\
+\sum_{i=0}^{n} \theta_{i} \Delta(G D P G)_{t-i}+e_{i}
\end{gathered}
$$

Whereas:

The Equation 7 describes the long-run stability adjustment when a short -run dynamic model has disordered. $\Delta \mathrm{FDI}_{\mathrm{t}}$ is variation in explained variable at time $\mathrm{t}, \Delta \mathrm{TR}, \Delta \mathrm{RRI}, \Delta \mathrm{TD} \& \Delta \mathrm{GDPG}$ are variation in explanatory variables at time $\mathrm{t}-1$, and $\mathrm{e}_{\mathrm{i}}$ is the error term with $\mathrm{i}$, and by taking ECM at time $\mathrm{t}-1$ as intercept parameter for special case.

\section{Results \& Discussion}

Table-1. Augmented dickey-fuller test.

\begin{tabular}{c|c|c|c|c|c|c}
\hline \multirow{2}{*}{ Variables } & \multicolumn{3}{|c|}{ Level } & \multicolumn{3}{c}{ First Difference } \\
\cline { 2 - 7 } & Intercept & $\begin{array}{c}\text { Trend and } \\
\text { Intercept }\end{array}$ & None & Intercept & $\begin{array}{c}\text { Trend and } \\
\text { Intercept }\end{array}$ & $\begin{array}{c}\text { None } \\
\text { FDI }\end{array}$ \\
\cline { 2 - 7 } & 0.0681 & 0.0010 & 0.1005 & 0.0069 & 0.0069 & 0.0306 \\
\hline GDPG & 0.0126 & 0.0360 & 0.1319 & 0.0000 & 0.0000 & 0.0000 \\
\hline TD & 0.2734 & 0.6637 & 0.1600 & 0.0000 & 0.0000 & 0.0000 \\
\hline TR & 0.2059 & 0.0170 & 0.5995 & 0.0000 & 0.0000 & 0.0000 \\
\hline RRI & 0.0065 & 0.0326 & 0.0014 & 0.0000 & 0.0000 & 0.0000 \\
\hline
\end{tabular}

Table 1 shows that the FDI, GDP, TR and RRI have stationary at the level of integration but T.D. has stationary at $1^{\text {st }}$ difference level of integration at $5 \%$ level. Moreover, the stationary means the mean, variance and co-variance has constant some on the level and some on $1^{\text {st }}$ difference of integration. The level of integration where variables have become stationary that notify valid output.

\begin{tabular}{|c|c|c|c|c|}
\hline Variable & Coefficient & Std. Error & t-Statistic & Prob. \\
\hline $\mathrm{C}$ & 0.650640 & 0.774091 & 0.840522 & 0.4130 \\
\hline $\mathrm{D}(\mathrm{FDI}(-1))$ & 0.120871 & 0.193956 & 0.623184 & 0.5419 \\
\hline $\mathrm{D}(\mathrm{FDI}(-2))$ & -0.174399 & 0.183608 & -0.949843 & 0.3563 \\
\hline $\mathrm{D}(\mathrm{GDPG}(-1))$ & -0.081250 & 0.062989 & -1.289903 & 0.2154 \\
\hline $\mathrm{D}(\mathrm{GDPG}(-2))$ & -0.037009 & 0.050867 & -0.727573 & 0.4774 \\
\hline $\mathrm{D}(\mathrm{RRI}(-1))$ & 0.050036 & 0.039378 & 1.270659 & 0.2220 \\
\hline $\mathrm{D}(\mathrm{RRI}(-2))$ & -0.002422 & 0.035227 & -0.068764 & 0.9460 \\
\hline $\mathrm{D}(\mathrm{TR}(-1))$ & 0.053735 & 0.070240 & 0.765023 & 0.4554 \\
\hline $\mathrm{D}(\mathrm{TR}(-2))$ & -0.065094 & 0.053538 & -1.215846 & 0.2417 \\
\hline $\mathrm{D}(\mathrm{TD}(-1))$ & -0.066897 & 0.038097 & -1.755961 & 0.0982 \\
\hline $\mathrm{D}(\mathrm{TD}(-2))$ & -0.114315 & 0.035934 & -3.181298 & 0.0058 \\
\hline $\mathrm{FDI}(-1)$ & 0.394517 & 0.121070 & -3.258574 & 0.0049 \\
\hline GDPG $(-1)$ & 0.214683 & 0.069765 & 3.077223 & 0.0072 \\
\hline $\operatorname{RRI}(-1)$ & -0.044589 & 0.041721 & -1.068748 & 0.3010 \\
\hline $\mathrm{TR}(-1)$ & -0.060148 & 0.058356 & -1.030700 & 0.3180 \\
\hline $\mathrm{TD}(-1)$ & 0.087578 & 0.024858 & 3.523068 & 0.0028 \\
\hline R-squared & 0.816874 & - & - & - \\
\hline F-statistic & 0.001784 & - & - & - \\
\hline Durbin-Watson stat & 2.580776 & - & - & - \\
\hline
\end{tabular}

Table-2. Autoregressive Distributed Lag_Model.

Table 2 indicates that the Foreign Direct Investment, Gross Domestic Product, Tax Rate, Real Rate of Interest and Trade Deficit have significantly associated for a prolonged period. But the Gross Domestic Product and Trade Deficit have positively associated with Foreign Direct Investment. The coefficient values show that if a one-unit change in GDP and TD, it brings 0.3945 and 0.0875 variations in FDI respectively. Rsquare value proposed that overall 0.8168 variations in the model due to associated predicted variables. Similarly, the probability value of F-statistics shows a good fit of the model. The Durbin-Watson value is 2.5807 which indicates that there has no autocorrelation or serial correlation problem in the model. 
Table-3. Bound test

\begin{tabular}{l|c|c}
\hline Test Statistic & Value & Probability \\
\hline F-statistic & 5.9534 & 0.0027 \\
\hline Lower bound critical Value at 1\% & 3.79 & - \\
\hline Upper bound value at 5\% level & 4.85 & - \\
\hline Decision Criteria & Cointegration & - \\
\hline
\end{tabular}

Note: Decision Criteria at Lower and Upper-bound critical values.

Table 3 Indicates the Bond test approach for an estimate of the long-run relationship among predicted and dependent variables. In the above table, the Bond test is entertained with the Wald-test integration approach. Pearson et al. 2001 was addressed that variables would be associated with a prolonged period if upper bond value $<\mathrm{P}<5 \%$ of the $\mathrm{F}$-statistic of the Bond test. In Table 3, lower bond value = 3.79; upper bond value $=4.85 ; \mathrm{F}$-statistic $=5.9534$. Thus, an outcome shows that GDP and TD have a long run associated with FDI. So the decision criteria have co-integration

Table-4. Breusch-godfrey LM test \& breusch pagan godfrey test.

\begin{tabular}{l|c|c}
\hline Model's & F-Statistic & Probability \\
\hline Breusch-Godfrey LM Test & 3.433511 & 0.0612 \\
\hline Breusch Pagan Godfrey Test & 0.955194 & 0.5332 \\
\hline
\end{tabular}

Table 4 summarizes the Breusch-Godfrey LM test and the Breusch Pagan Godfrey test. Breusch-Godfrey LM test and Breusch Pagan Godfrey test are used to diagnose the problems of Autocorrelation and Hetroskedasticity respectively. In the above table, F-statistic $=3.433511 \& \mathrm{P}=0.0612$ of Breusch Godfrey LM test values that execute that there is no autocorrelation or serial-correlation problem in the model because the probability value is greater than $5 \%$. Similarly, F-statistic $=0.955194 \&$ probability $=0.5332$ of Breusch Pagan Godfrey Test which indicates that there is no heteroskedasticity error because the probability value has greater than $5 \%$.

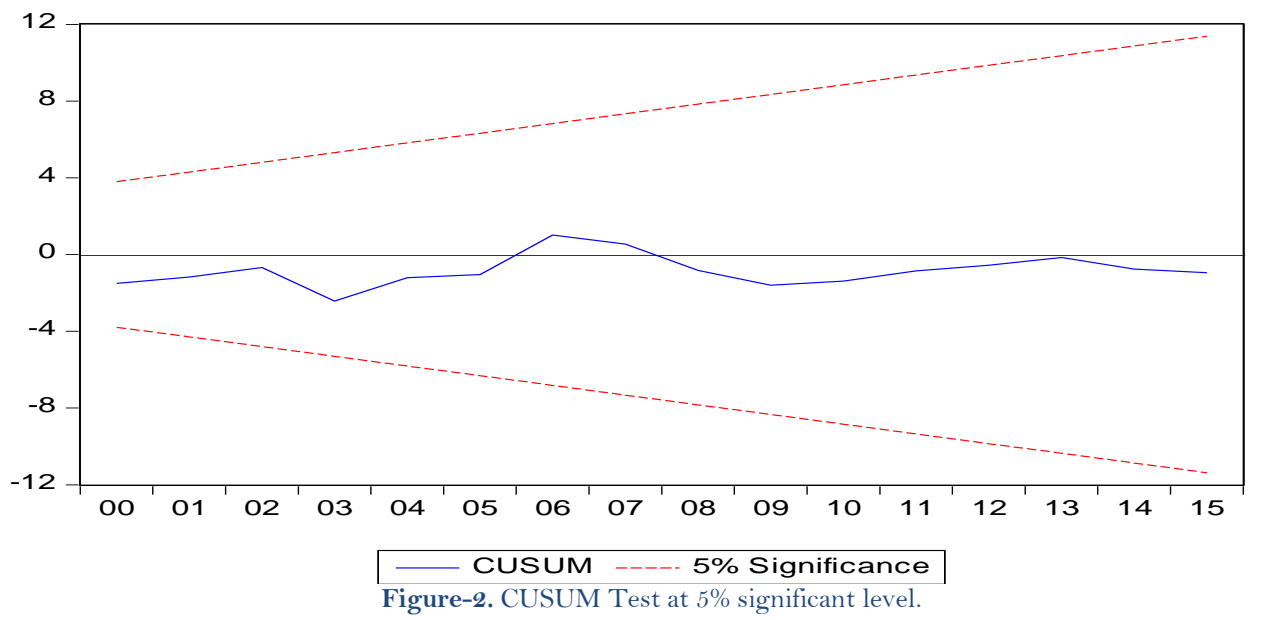

Figure 2 has contained on cumulative sum of deviations (CUSU test that estimates the stability of the ARDL model. Belloumi (2014) was used similar technique (CUSUM) to concise the relationship of foreign direct investment and gross domestic product of Tunisia. In above figure has consisted of four-color lines where light rid colour lines are the boundary of stability of the model and the blue colour line represents the stability of the model. Consequently, the above figure precisely our model has highly stabilized because the blue line has in between rid lines.

\section{Conclusions}

The main objective of this research is to determine the association between GDP growth, TR, RRI and TD with FDI. The results indicate that there is a positive and significant relationship between trade deficit and foreign direct investment as well as the relationship of G.D.P. growth and FDI. Moreover, the Tax Rate and the real rate of interest have neither positive nor negative associations with foreign direct investment. The Pakistani-government have needed to construct a novel and strong fiscal policy. The policy of dependency on taxation which makes enhancement or attraction for foreign investors for investment. The efficient capital and financial structure should be introduced, and the export-led growth strategy by decreasing the trade tariff should be adapted and open the new sector for investment. The housing and construction sector has the potential to grow if the possible facilities and concessions will be given to foreign investors by the government. 


\section{References}

Agiomirgianakis, G. M., Asteriou, D., \& Papathoma, K. (2003). The determinants offoreign direct investment: A panel data study for the OECD countries (03/06). London, UK: Department of Economics, City University London.

Ali, M., \& Malik, I. R. (2017). Impact of foreign direct investment on economic growth of Pakistan. Paper presented at the Asian Multidisciplinary Conference, Asia Metropolitan University, Cyberjaya Campus, Malaysia.

Bachmann, C., \& Baumann, M. (2013). Effective tax rates: The role of tax rates in investment decisions. Journal of Business Cases and Applications, $8,1$.

Belloumi, M. (2014). The relationship between trade, FDI and economic growth in Tunisia: An application of the autoregressive distributed lag model. Economic Systems, 38(2), 269-287. Available at: https://doi.org/10.1016/j.ecosys.2013.09.002.

Boddy, C. R. (2016). Sample size for qualitative research. Qualitative Market Research: An International Journal, 19(4), 426432. Available at: https://doi.org/10.1108/QMR-06-2016-0053.

Chingarande, A., Karambakuwa, R. T., Webster, D., Tafirei, F., Onias, Z., Muchingami, L., \& Mudavanhu, V. (2012). The impact of interest rates on foreign direct investment: A case study of the Zimbabwean economy (February 2009June 2011).

de Angelo, C. F., Eunni, R. V., \& Fouto, N. M. M. D. (2010). Determinants of FDI in emerging markets: evidence from Brazil. International Journal of Commerce and Management.

Deng, Z., Falvey, R., \& Blake, A. (2012). Trading market access for technology? Tax incentives, foreign direct investment and productivity spillovers in China. Journal of Policy Modeling, 34(5), 675-690.

Faroh, A., \& Shen, H. (2015). Impact of interest rates on foreign direct investment: Case study Sierra Leone economy. International Journal of Business Management and Economic Research, 6(1), 124-132.

Galan, J. I., \& Gonzalez-Benito, J. (2001). Determinant factors of foreign direct investment: Some empirical evidence. European Business Review, 13(5), 269-278. Available at: https://doi.org/10.1 108/eum000000005795.

Hartman, D. G. (1984). Tax policy and foreign direct investment in the United States. National tax journal, 475-487.

Ibrahim, T. (2019). Determinants of FDI: Evidence from developed \& developing countries.

Jones, A., Fallon, G., \& Golov, R. (2000). Obstacles to foreign direct investment in Russia. European Business Revierw, 12(4), 187-197. Available at: https://doi.org/10.1108/09555340010336871.

Kersan-Škabić, I. (2015). The importance of corporate taxation for FDI attractiveness of southeast European countries. Panoeconomicus, 62(1), 105-122. Available at: https://doi.org/10.2298/pan1501105k.

Kinuthia, B. K., \& Murshed, S. M. (2015). FDI determinants: Kenya and Malaysia compared. Journal of Policy Modeling, 37(2), 388-400. Available at: https://doi.org/10.1016/j.jpolmod.2015.01.013.

Lu, Y., Tao, Z., \& Zhu, L. (2017). Identifying FDI spillovers. Journal of International Economics, 107, 75-90. Available at: https://doi.org/10.1016/j.jinteco.2017.01.006.

Malik, I. A., \& Amjad, S. (2013). Foreign direct investment and stock market development in Pakistan. Journal of International Trade Law and Policy, 12(3), 226-242. Available at: https://doi.org/10.1108/jitlp-02-2013-0002.

Masso, J., Roolaht, T., \& Varblane, U. (2013). Foreign direct investment and innovation in Estonia. Baltic Journal of Management, 8(2), 231-245. Available at: https://doi.org/10.1108/17465261311310036.

Nkoro, E., \& Uko, A. K. (2016). Autoregressive distributed lag (ARDL) cointegration technique: Application and interpretation. Journal of Statistical and Econometric Methods, 5(4), 63-91.

Rajasekar, S., Philomonathan, P., \& Chinnathambi, V. (2006). Research methodology. arXiv. arXiv preprint physics/0601009.

Sahoo, D., \& Das, A. B. (2012). ARDL co-integration approach to the external and internal sector equilibrium of India. Procedia-Social and Behavioral Sciences, 62, 812-816. Available at: https://doi.org/10.1016/j.sbspro.2012.09.137.

Sandhu, N., \& Gupta, N. (2016). Determinants of inward foreign direct investment (1994-2014): The case of India. SCMS Journal of Indian Management, 13(4), 83-94.

Shankar, R., \& Yadav, S. S. (2014). Foreign direct investment and current account deficit. Journal of Advances in Management Research, 11(2). Available at: https://doi.org/10.1108/JAMR-05-2014-0028.

Siddiqui, H. A. A., \& Aumeboonsuke, V. (2014). Role of interest rate in attracting the FDI: Study on ASEAN 5 economy. International Journal of Technical Research and Applications, 2(3), 59-70.

Trevino, L. J., \& Grosse, R. (2002). An analysis of firm-specific resources and foreign direct investment in the United States. International Business Review, 11(4), 431-452. Available at: https://doi.org/10.1016/s0969-5931(02)000185 .

Vegh, C. A. (2015). Fiscal policy in emerging markets: Procyclicality and graduation. NBER Reporter, 4, 8-12. 